\title{
Stress Coping Strategies among Agricultural Extension Agents in Oyo State, Nigeria \\ Http://dx.doi.org/10.4314/jae.v20i1.14
}

\section{Bolarinwa K. K.}

Department of Agricultural Administration

Federal University of Agriculture Abeokuta Nigeria

bkolade@gmail.com

Phone: +2348058048158

\section{Ayinde A.F.O}

Department of Agricultural Administration

Federal University of Agriculture Abeokuta Nigeria

Email: funkeayinde@yahoo.com

\section{Adeogun S.O.}

Department of Agricultural Administration

Federal University of Agriculture Abeokuta Nigeria

Email: adeogun lizzyste@yahoo.com

\section{Abstract}

The study examined the coping strategies used by extension agents $A$ total of seventy 72agricultural extension agents were randomly sampled out of 288 agricultural extension agents from the four zones (Saki, Oyo, Ogbomosho, and Ibadan) in the Oyo State Agricultural Development Programme (OYSADEP). A questionnaire was used for data collection while the data were analysed using descriptive and inferential statistics. Out of 11 job stressors, the predominant job stressors carried out by the extension agentswere farmers field visitation with ( $\bar{x}=4.80)$,training of farmers $(\bar{x}=4.76)$ and establishment of SPAT (small plot adoption techniques $)(\bar{x}=4.59)$ Reading newspaper, magazine or book $(\bar{x}=1.77)$ and discussing work situation with spouse or close friends $(\bar{x}=1.5)$ were the major coping strategies used in overcoming job stress while negative coping strategies such as becoming aggressive recorded low mean score of 0.34. There was strong relationship between some job stressors and coping strategies employed by workers. Employees should have control over work flow to reduce work stress and increase work efficiency.

Keywords: Extension agentswork stress, stressors and copying strategies Introduction

Stress arises within an organization when employees feel under pressure if the demands of their job (such as hours of responsibilities) are greater than they can comfortably manage. Stress is related to the organization; for example, when there are bad management practices, lack of support between employer and employee, 
Creative commons User License: CC BY-NC-ND

Abstracted by: EBSCOhost, Electronic Journals Service (EJS),

Google Scholar, Directory of Open Access Journals (DOAJ),

Journal Seek, Scientific Commons,

Food and Agricultural Organization (FAO), andCABI
Journal of Agricultural Extension

Vol. 20 (1) June, 2016

ISSN(e): 24086851; ISSN(Print); 1119944X

http://journal.aesonnigeria.org

http://www.ajol.info/index.php/iae

Email: editorinchief@aesonnigeria.org

changes in management, focus on job content and demands. Therefore, stress is caused by heavy workload, job insecurity, the threat of job loss or redundancy and conflict with other workers or superiors. However, the extent to which stress is experienced depends on how people cope with stress situation (George and Jones, 1999).

Stress can be experienced from four basic sources: the environment, that is, the environment can bombard someone with intense and competing demands to adjust. Examples of environmental stressors include weather, noise, crowding, pollution, traffic, unsafe and substandard housing and crime. Social stressors can be experienced through the demands of different social roles people occupy, such as parent, spouse, caregiver, and employee. Some examples of social stressors include deadlines, financial problems, job interviews, presentations, disagreements, demands for your time and attention, loss of a loved one, divorce, and co-parenting. Physiological situations and circumstances affecting our body can be experienced as physiological stressors. Examples of physiological stressors include rapid growth of adolescence, menopause, illness, aging, giving birth, accidents, lack of exercise, poor nutrition, and sleep disturbances. The fourth is thoughts, for instance, the brain interprets and perceives situations as stressful, difficult, painful, or pleasant (Davis, Eshelman, \& McKay 2008).

Some situations in life are stress provoking, but it is our thoughts that determine whether they are a problem for us. Hence, coping with job stress is a key concept in understanding people's adaptation to their work roles. In their jobs employees are confronted with various kinds of demands, which may become 'stressors' when they tax or exceed the employee's adaptive capabilities. Examples of common job stressors include work overload, role problems, poor job control, and lack of support from supervisors and co-workers, and interpersonal conflicts. These stressors may lead to negative psychological (e.g., depression, irritability, burnout), physical (e.g., headaches, heart palpitations, hyperventilation) and behavioral (e.g., absenteeism, turnover, violence) symptoms or 'strains'( Schaufeli,2001). The psychological process that is involved in dealing with these job stressors in order to reduce strain is called coping. More specifically, coping with job stress refers to the things employees do to handle the stressors they encounter in their work roles. These individual coping efforts may or may not be supported by the employing organization.

Earlier studies on coping with job stress by Latack and Havlovic (1992) often found that employees use fewer problem-focused than emotion-focused strategies directed at changing the problems encountered in the context of work. This was interpreted by noting that the very natures of problems at work are perhaps not ameliorated easily by attempts to change them. It was reasoned that employees are perhaps better off by developing a renewed cognitive perspective and by regulating their negative emotions. 
Creative commons User License: CC BY-NC-ND

Abstracted by: EBSCOhost, Electronic Journals Service (EJS),

Google Scholar, Directory of Open Access Journals (DOAJ),

Journal Seek, Scientific Commons,

Food and Agricultural Organization (FAO), andCABI
Journal of Agricultural Extension

Vol. 20 (1) June, 2016

ISSN(e): 24086851; ISSN(Print); 1119944X

http://journal.aesonnigeria.org

http://www.ajol.info/index.php/iae

Email: editorinchief@aesonnigeria.org

Furthermore, it is the task of the employers and employees to prevent stress in the workplace because it has benefit. In preventing stress in the workplace there will be greater job satisfaction which will increase job engagement, increase the productivity of the organisation and few injuries, less illness, lost time which will also improve employee health and community wellbeing (Better Health Center,2015). Therefore, managing job stress with various coping strategies in an organization such as Oyo State Agricultural Development Programme will be a tool for reducing symptoms of poor mental and physical health of employees. Job stress is a reality of current day life; the issue of job stress causes a great deal of stress to the employees. Job or workplace stress has become one of the most serious health issues in the modern world as it occurs in any job. It is a growing problem in an organization that affects not only the health and wellbeing of employee but also the productivity of organizations.

In many developing countries agricultural development is hinged on extension service providers by helping farmers to identify and link them with research that provides solution to their production problems. They also provide awareness on opportunities for improvement of farm yields leading to increased income and better standard of living through the dissemination of information on agricultural technologies and improved practices to farm families (Van den Ban and Hawkins 1998). Poor financing of extension programmes has been a long standing problem facing the services since the World Bank withdraw its support (Adams, 1984). This has resulted in problem with mobility whereby extension agents would have to wait to the point of demoralization before delivering their services to farmers. In 1997, Nigeria had 6,563 extension agents; with an extension agent farmer's ratio of 1:1615. This is in sharp contrast to 1: 252 and 1: 500 found in Japan and South Korea respectively (Agbamu ,1998). Edeoghon, and Idele, (2012) stated that presently in Nigeria, the ratio is between 15,000 and 20,000 farmers to one extension worker in contradiction to the World Bank recommended ratio of one extension worker to 800 farmers. (1:800). These ratios suggest that extension service provider's hours of work per day and the overall workload would be very huge. There is an enormous demand on extension providers by the clientele and the institutions they serve. These demands predispose them to frustrations and stress (Kutilek, Conklin, and Gunderson, 2002; Bolarinwa,2012). These processes easily lead to burnout among extension agents which is defined as extreme tiredness usually caused by working too much. That is, they lose most of their energy and enthusiasm for work because of having worked too much for too long periods under stress. According to Bolarinwa (2012) Oyo state Agricultural Development Programmeextension agentsare exposed to severe stress.

\section{Purpose of the Study}

The study examined the coping strategies used by extension agents. Specifically, the study examined activities that agricultural extension providers embarked on that cause stress, ascertain employees job stressors coping strategies and determine level of relationship between job stressors and coping strategies. 
Creative commons User License: CC BY-NC-ND

Abstracted by: EBSCOhost, Electronic Journals Service (EJS),

Google Scholar, Directory of Open Access Journals (DOAJ),

Journal Seek, Scientific Commons,

Food and Agricultural Organization (FAO), andCABI
Journal of Agricultural Extension

Vol. 20 (1) June, 2016

ISSN(e): 24086851; ISSN(Print); 1119944X

http://journal.aesonnigeria.org

http://www.ajol.info/index.php/jae

Email: editorinchief@aesonnigeria.org

\section{Methodology}

This study was based on the Oyo State Agricultural Development Programme that made use of Extension Agents(EAs). Also it is an agricultural extension arm of Ministry of Agriculture, Oyo State. Thirty-six extension service providers were randomly sampled from each zone to give 72 EAs that were randomly sampled out of 288 EAsin the four administrative zones of OYSADEP. However, 70EAs were finally participated in the research. Sources of data included the use of structured questionnaire to obtain information from the extension service providers.

The questionnaire contained items which provided solutions to these set of objectives. Job stressor was measured by asking the EAs to rate which of the schedule of duties/workload gave them stress, using 5 point Likert type rating scale, with rating scale ranging from $0-4$. The cut off score point for an activity to be classified as work stressor is 2.5. The dependent variable, coping strategies were measured by adapting measuring scale developed by Anspaugh and Michael (2009). The scale consists of 20 items with the rating scale of often used $=2$, Rarely used $=1$, not all $=0$. The cut of point score for items on the scale is 1.5. Data collected were analysed using descriptive and inferential statistics. Least Squares regression model was used in analysing the relationship between job stressors and job stressor coping strategies. The model was specified as follows:

$\mathrm{CPSG}=\mathrm{A}_{0}+\mathrm{A}_{1} \mathrm{DRF}_{1+} \mathrm{A}_{2} \mathrm{ROL}_{2}+\mathrm{A}_{3} \mathrm{ATS}_{3}+\mathrm{A}_{4} \mathrm{TROF}_{4}+\mathrm{A}_{5} \mathrm{EPWP}_{5}+\mathrm{A}_{6} \mathrm{COAF}_{6}$ $+\mathrm{A}_{7} \mathrm{ATWS}_{7}+\mathrm{A}_{8} \mathrm{ROF}_{8+}$

$$
\mathrm{A}_{9} \mathrm{FEV} \mathrm{V}_{9}+\mathrm{A}_{10} \mathrm{ESTSP}_{10}+\mathrm{A}_{11} \mathrm{FCG}_{11}+\mathrm{U} \text {. }
$$

CPSG $=$ Job stressor coping strategies

DRF = Demonstration of result to farmers

$\mathrm{ROL}=$ Rendering of lectures

TROF $=$ Training of farmers

EPWP $=$ Empowerment programme

COAF = Consultancy to other agricultural firms

ATWS = Attending workshop

ROF = Registration of farmers

$\mathrm{FEV}=$ Farmers field visitation

ESTSP $=$ Establishment of Small Plot Adoption Techniques (SPAT)

$\mathrm{FCG}=$ Forming contact group

Coefficient of determination $\mathrm{R}^{2}$ is the variation in job stress coping strategies that explained by the job stressors. Hence, when the percentage variation is less than $50 \%$ such job stressor has a weak relationship with the job stressor coping strategies. However, if the job stressor has percentage greater or equal to $50 \%$ such job stressor has a strong relationship with job stressor coping strategies 


\section{Results and Discussion}

\section{Personal Characteristics of Extension Agents}

As shown in Table1 the mean age of the extension service providers was 43.36; this implies that majority (64.3\%) of the extension agents were in their active age of less than 45 years. It could be inferred from the result that they have many years to contribute to the achievement of the organisational goals. The data supports the findings of Adegbite and Olaoye (2009) who also recorded a high proportion of the employees within the age bracket of 20-50 years. Also $68.7 \%$ of the extension agents were male while $31.4 \%$ were females. This result supports the findings of (Rarieya, 2013) who reported that in South Africa, men are more employed than women in almost every organization. The result also indicates that $92.9 \%$ of the extension agents were married, while $55.7 \%$ and $44.3 \%$ of the employees were Christians and Muslim, respectively. These findings are expected because Christianity and Islam dominate this part of the country and religious belief is one of the ways to manage stress. The result from Table1 further indicates that majority $(95.3 \%)$ of theextension agents had education that is above senior secondary school certificate. The result indicated $50.0 \%$ of the extension agents had been working with the organisation for more than $10 y e a r s$. It could be inferred from the result that the employees are highly experienced and they are likely to be subjected to work stress. These results support the findings of $\mathrm{Li}$ et al. (2007) who report that employees with less than or equal to 10 years of working experience express less work stress because they are in the early years of their career making therefore, they enjoy their job to the fullest. Also, it was revealed that only $7.1 \%$ of the extension agents earned less than or equal to $\# 30,000$ per month and the average mean income of extension service providers was N52,214.29 per month. 


\section{Table1: Percentage distribution of extension agents according to socio-} economic characteristics

\begin{tabular}{lcc}
\hline Socio-economic Characteristic & Percentage(n=70) & Mean \\
\hline Age & 15.7 & 43.6 \\
Less than or equal to 35years & 48.6 & \\
36-45years & 27.1 & \\
46-55years & 8.6 \\
56years and above & & \\
Sex & 68.6 \\
Male & 31.4 \\
Female & 92.9 \\
Marital status & 7.1 \\
Married & \\
Single & 44.3 \\
Religion & 55.7 \\
Islam & 4.3 \\
Christianity & 10.0 \\
Educational level & 24.3 \\
SSCE & 35.7 \\
NCE/OND & 25.7 \\
HND & \\
BSC & 30.0 \\
MSC & 44.3 \\
Rank/cadre & 10.0 \\
Senior staff/Executive officer & 11.4 \\
Agric Officer & 4.3 \\
Planning Officers & & \\
Junior staff & 50.0 \\
Chief technology & 30.0 \\
Working experience & 20.0 \\
Less than or equal to 10years & \\
11-20 years & 7.1 \\
Above 21years & 44.4 \\
Income per month & 51.4 \\
Less than or equal to \#30,000 & 5.7 \\
\#31,000 - \#50,000 & \\
\#51,000 - \#70,000 & \\
\#71000 - \#90,000 & \\
Above \#91,000 & \\
\hline
\end{tabular}

Source: Field Survey, 2015

\section{Job Stressor Activities in the Organisation}

As shown in Figure 1 out of 11 job stressors, the predominant job stressor carried out by extension agents were farmers field visitation (4.80), training of farmers (4.76) and establishment of SPAT (4.59). These job stressors were ranked 1, 2, and 3, respectively by extension agents. All the activities carried out by extension agents generate stress because none of the job stressor scored below cut off point of 2.5 as indicated in figure1. Hence the extension agents will be experiencing the symptoms of stress such as loss of appetite, fatigue and fearfulness. 


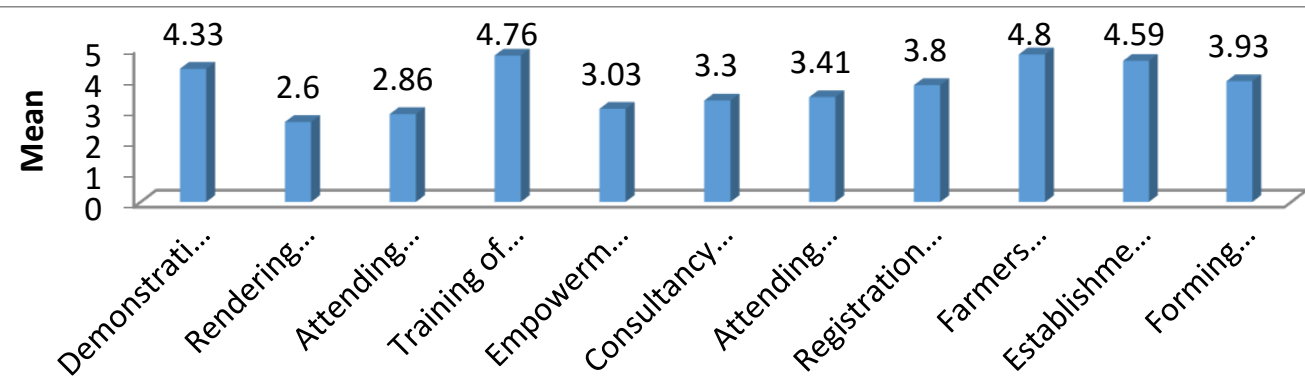

Job Stressor Activities

\section{Figure 2: Mean of job stressors activities}

\section{The Coping Strategies used in Overcoming Job Stress}

The result in Figure2 reveals that reading a newspaper, magazine, or book, discussion of work situations with a spouse or close friends, praying, go to church and listen to music $(x=1.77,1.54,1.54,1.51$, respectively were coping strategies employed by extension service providers to overcome stress in the organization. With the extension service providers listening to music, according Hanser (2016) they will likely be able to cope with the following stress situation: elevating their mood, evoke their memory, relaxing their nerves and provoke their attention. Also prayer will enable them to have positive coping devices that could be directed toward both problems solving and facilitating personal growth. Hence, prayer evokes a relaxation response that quells stress, quiets the body, and promotes healing (Spilka etal 2003, Davis, 2001). It could be inferred from the Figure2 that negative coping strategies such as becoming aggressive (0.34), get drunk (0.14) and smoke tobacco (0.13) had low mean scoreswere not frequently/highly used as strategies to cope with stress in the organization. 


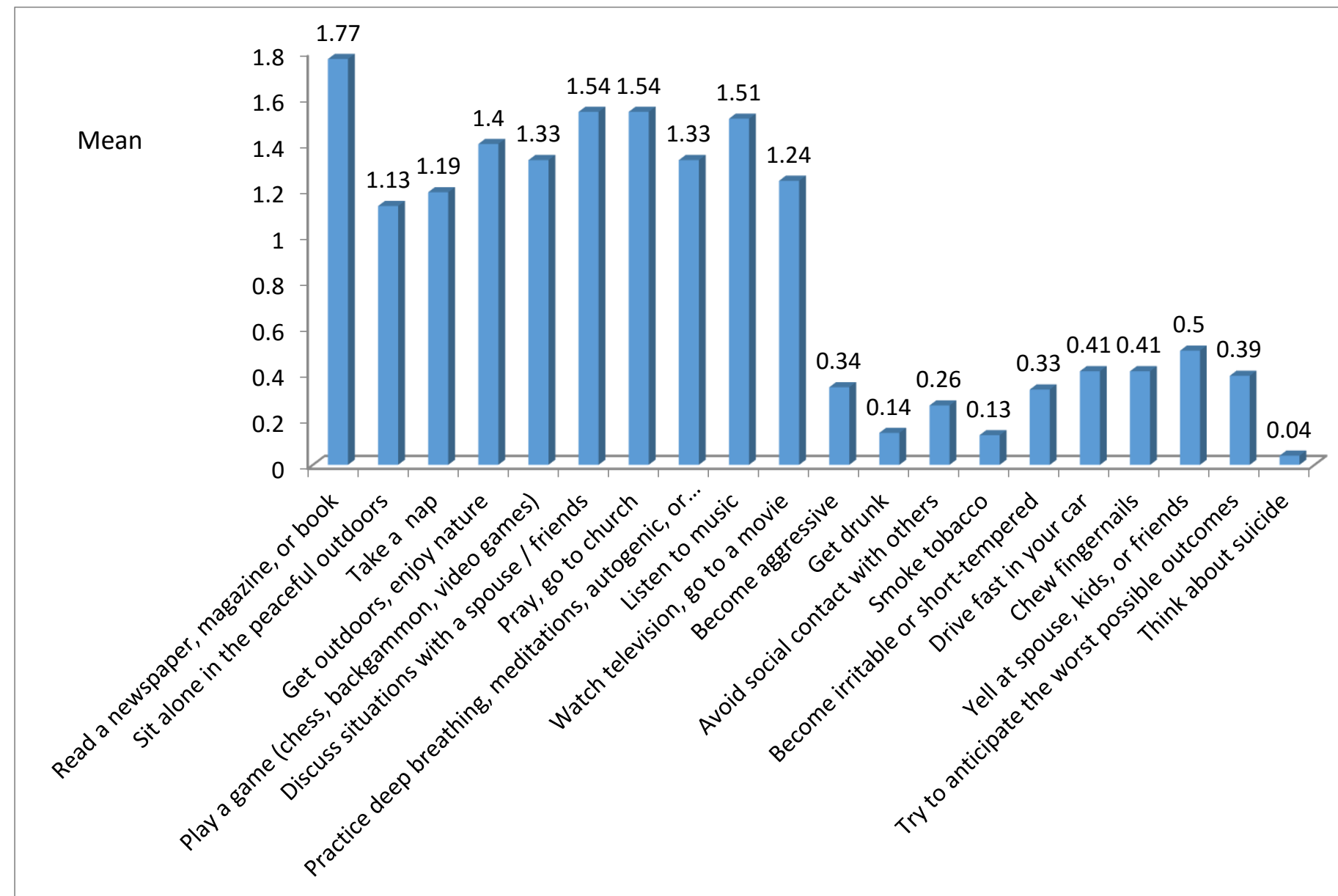

\section{Figure 2: Mean of coping strategies used in overcomingjob stress Relationship between Job Stressor and Coping Strategies.}

able 2 reveals that there is a weak relationship between the following work stressors; demonstration of result to farmers $\left(R^{2}=0.071\right)$, attending seminars $\left(R^{2}=\right.$ 0.068 ) attending workshop $\left(R^{2}=0.110\right)$, registration of farmers $\left(R^{2}=0.186\right)$, and extension service providers coping strategies. The implication of this is that the available coping strategies cannot reduce stress created by these job stressors in extension service providers. Also the following job stressosr; training of farmers $\left(R^{2}=\right.$ $0.342)$, empowerment programme $\left(R^{2}=0.226\right)$, consultancy to other agricultural firms $\left(R^{2}=0.265\right)$, and forming contact groups $\left(R^{2}=0.201\right)$ have moderate relationship with coping strategies. However, the result also shows that there is a strong relationship between establishment of SPAT $\left(R^{2}=0.644\right)$, field visitation $\left(R^{2}=0.523\right)$, rendering of lectures $\left(R^{2}=0.516\right)$ and stress coping strategies. This implies that the coping strategies are sufficiently used by the extension agents in coping with these job stressors in the organisation. 
Table 2: Relationship between job stressors and coping strategies using regression analysis

\begin{tabular}{|c|c|c|c|}
\hline S/N Activities carried out that cause job stress & $\mathrm{B}$ & $\mathrm{R}^{2}$ & Std Error \\
\hline 1 Demonstration of result to farmers & 0.275 & 0.071 & 0.573 \\
\hline 2 Rendering of lectures & -0.111 & 0.516 & 0.819 \\
\hline 3 , Attending seminars & 0.352 & 0.068 & 0.745 \\
\hline 4. Training of farmers & -0.223 & 0.342 & 0.884 \\
\hline 5. Empowerment programme & -0.217 & 0.226 & 0.689 \\
\hline 6. Consultancy to other agricultural firms & 0.199 & 0.265 & 0.717 \\
\hline 7. Attending workshop & -0.313 & 0.110 & 0.798 \\
\hline 8. Registration of farmers & -0.313 & 0.186 & 0.872 \\
\hline $\begin{array}{l}\text { 9. Field visitation } \\
\text { 10. Establishment of SPAT (Small Plot Adoption }\end{array}$ & 0.142 & 0.523 & 0.836 \\
\hline Techniques) & 0.105 & 0.644 & 0.870 \\
\hline 11. Forming contact group & 0.300 & 0.201 & 0.911 \\
\hline
\end{tabular}

Source: Field Survey, 2015

\section{Conclusion and Recommendations}

The predominant job stressor were; farmers field visitation followed by training of farmers and establishment of SPAT (Small Plot Adoption Techniques). Reading newspaper, magazine or book, discuss situation with spouse or close friends and pray, go to church and listen to music were the major coping strategies used in overcoming job stress in the organisation. The strategies for coping with stress have strong, moderate and weak relationship with some job stressor. It is recommended that extension programme managers and those concern with agricultural development understand these conditions in managing extension workers to enhance stress coping strategies. Service providers should have control over work flow to reduce work stress and increase work efficiency.

\section{References}

Adams, M. E., (1984). Agricultural Extension in Developing Countries second Edition, Longman Group Itd, Essex, Pp 3-4

Adegbite, D. A., \& Olaoye, O.J. (2009): Performance assessment of OSAMCA in credit delivery and operation (2004-2006). Journal of sustainable development in Africa, 10(4), 365 - 387

Agbamu, J.U., (1998). A study on Agricultural Research-Extension linkages: with focus on Nigeria and Japan Ph. D Thesis, Tokyo University of Agriculture, Tokyo, Pp 194-195

Anspaugh, D.J. \& Michael, H, (2009) Wellness: Concepts and application ; $7^{\text {th }} \quad$ ed at the McGraw Hill Companies,Inc 
Davis, M., Eshelman, E.R., \& McKay, M. (2008). The relaxation and stress reduction workbook. Oakland, CA: New Harbinger Publications, Inc

Davis, J. (2001). Can prayer heal? Saturday Evening Post, 273(6), 14-17.

Edeoghon, C. O. \& Idele, B. O. (2012). Extension Agents' Perception of Factors Affecting Dissemination of Improved Farm Technologies in Agricultural Development Programme South Zone of Edo State, Nigeria. Nigerian Journal of Agriculture, Food and Environment. 8(3):62-66

George, J.M. \& Jones, G. R. (1999). Understanding and Managing organizational Behavior. $2^{\text {nd }}(\mathrm{Ed})$. Addison-Wesley Publishing Company, Inc. pp295-31.

Hanser , S. (2016).Music Therapy-Based Mechanisms for Coping with Stress and Pain www.cujucr.com/downloads/.../6/vol6\%20Suzanne\%20Hanser.pdf accessed in 2016

Rarieya F.A (2013).Women leaders in the workplace:The intangible barrier: www.hsrc.ac.za/en/review/hsrc-review-july-2013/women-leaders- inthe. accessed in February2016

Kutilek, L,M, Conklin, N.L \& Gunderson G. (2002). Investing in the future: addressing work/life issues of employees. Journal of extension (online) 40

(1): available at http://www.joe.org/joe/2002february/a6html

Lietal, Y. X., Yang, X., \&Shen, J. L. (2007). The relationship between teachers' sense of teaching efficacy and job burnout. Psychological Science (China), 30, 952-954.

Latack J C, Havlovic S J (1992). Coping with job stress: A conceptual evaluation framework for coping measures. Journal of Organizational Behaviour 13: 497-508

Schaufeli W.B; Demerouti, E.; Bakker, A.B., De Jonge, J., Janssen, P.P.M. \&Schaufeli, W.B. 2001) Job Stress, Coping with Sources of Work Stress Inventory: Technical Manual. Johannesburg: Jopie van Rooyen\& Partners.

Spilka, B., Hood, R. W. Jr., Hunsberger, B., \& Gorsuch, R. (2003). The psychology of religion: An empirical approach. New York: Gilford.

Van Den Ban, A.W. \& Hawkins, H.S (1998). Agricultural Extension, second Edition, Blackwell Science Publication Oxford pp 267-268 